\title{
A MULTIMODAL ANALYSIS OF MATHEMATICAL DISCOURSE IN ENGLISH FOR YOUNG LEARNERS
}

\author{
Ton Nu My Nhat* \\ Department of Foreign Languages, Quy Nhon University \\ 170 An Duong Vuong, Quy Nhon, Binh Dinh, Vietnam \\ Received 09 October 2017 \\ Revised 02 November 2017; Accepted 27 November 2017
}

\begin{abstract}
Of multiple discourses where the Vietnamese young learners are increasingly engaged to develop their English proficiency, English mathematical discourse (MD) has proved to be more and more popular. This paper explores the materials in this realm from multisemiotic perspective. In particular, it deals with two questions: (1) to what extent each of the three semiotic resources - language, visual images and mathematical symbolism - is represented in the materials of learning mathematics in English (ME) developed for young learners (YL) and (2) how many words the YLs need to know to comprehend the language component of these materials. Data for illustrations and discussions are withdrawn from the printed resources currently accessible in the Vietnamese context. The results offer insights into the functions of other resources in constructing meanings apart from the well-established role of language as well as the vocabulary load of these materials. The paper concludes with a discussion of pedagogical significance of this study for material designers, teachers and learners and implications for further research.
\end{abstract}

Keywords: mathematical discourse, multisemiotic discourse, high frequency word list

\section{Introduction}

Mathematic Discourse (MD) is referred to as multisemiotic as it is constructed from more than one semiotic resource - language, visual images and mathematical symbolism (O'Halloran 2004, p.21). The view of mathematics as a multisemiotic discourse is significant in a pedagogical context as a better understanding of the functions of mathematical symbolism and visual images permits a re-evaluation of the role of language in the construction of meaning in this naturalized domain. Such an understanding proves to be even more essential in the case of content and language integrated learning (CLIL) in a foreign context, where the learners have to cope with both mathematic problems per se and a foreign language.

This study is an attempt to investigate MD written in English for primary school learners.

${ }^{*}$ Tel.: 84-905242270

Email: tnmynhat70@gmail.com
Specifically, the present study examines the following research questions: (1) To what extent is each of the three semiotic resources represented in the materials of learning mathematics in English (ME) developed for young learners (YLs)? and (2) How many words do YLs need to know to understand the vocabulary in ME and to what extent can these materials enhance incidental vocabulary learning? Two major areas of interest are the lexis specific to the field of Mathematics and that to children's everyday world.

\section{Mathematical discourse}

O'Halloran's (2004) study can be best viewed as a first step towards a comprehensive Systemic-functional Grammar for MD. The major concern of this study is to investigate the multisemiotic nature of MD. She developed theoretical frameworks for mathematical symbolism and visual display. 
As reviewed in O'Halloran's (2004, pp. 13-15) the multisemiotic approach, where language, visual images and mathematical symbolism are considered semiotic resources, originally stems from O'Toole's (1994, 1995, 1999) extensions of Halliday's (1978, 1994) Systemic-funtional approach to displayed art, and Lemke's (1998, 2000, 2003) early work in mathematical and scientific discourse. Following are the central tenets which are relevant to the present study.

(1) MD is considered as 'multisemiotic' construction; that is, discourses formed through choices from the functional sign systems of language, mathematical symbolism and visual display.

(2) MD involves language, mathematical symbolism and visual images. The functions of each semiotic resource may be summarized as follows. Patterns of relations are encoded and rearranged symbolically for the solution to the problem. Due to the limited functionality of the symbolism, language functions as the meta-discourse to contextualize the problem, to explain the activity sequence which is undertaken for the solution to the mathematics problem. Visual images in the form of abstract and statistical graphs, geometrical diagrams, and other types of diagrams and forms of visual display, mirror our perceptual understanding of the world, showing the relations in a multi-dimensional spatio-temporal format. They thus connect and extend common-sense experience to the mathematical symbolic descriptions.

(3) MD depends on both intrasemiosis and intersemiosis. As the types of meaning made by each semiotic resource are fundamentally different (p.16), and thus the three semiotic resources fulfil individual functions, the success of mathematics depends on utilizing and combining the unique meaning potentials of language, symbolism and visual display in such a way that the semantic expansion is greater than the sum of meanings derived from each of the three resources. Intersemiosis refers to meaning which arises from the relations and shifts across the three semiotic resources; Intrasemiosis is meaning within one semiotic resource. Royce (1998, p. 26, cited in O'Halloran, 2004: 159) refers to intersemiosis as 'intersemiotic complementarity' where 'visual and verbal modes semantically complement each other to produce a single textual phenomenon'. As Royce and Lemke (1998, cited in O'Halloran 2004, p. 159) explain, the product is 'synergistic' or 'multiplicative' in that the result is greater than the sum of the parts.

\section{Language, symbolism and visual images function together in mathematical discourse to create a semantic circuit which permits semantic expansions beyond that possible through the sum of the three resources. Following this view, the success of mathematics as a discourse stems from the fact that it draws upon the meaning potentials of language, visual images and the symbolism in very specific ways. That is, the discourse, grammar and display systems for each resource have evolved to function as interlocking system networks rather than isolated phenomena. (O'Halloran 2004: 159)}

(4) Mathematical printed texts are typically organized in very specific ways which simultaneously permit segration and integration of the three semiotic resources ( $p$. 11). The systems of meaning for language, symbolism and visual images are integrated in such a way that the behaviour of physical systems may be described. Choices from the three semiotic resources function integratively. That is, the linguistic text and the graphs contain symbolic elements and the symbolic text contains linguistic elements. The symbolic elements may also be either spatially separated from the main body of the linguistic text or embedded within the linguistic text. 


\section{Methodology}

\subsection{Materials}

The books which served as the data of the present study comprise two sets. The first set consists of two books published by Vietnam Education Publishing House - Math ViOlympic 4 (Đặng Minh Tuấn \& Nguyễn Thị Hải, 2016) and Math ViOlympic 5 (Đặng Minh Tuấn \& Nguyễn Thị Bích Phượng, 2016); the second is two books published by Singapore Asia Publishers - Learning Maths $1 B$ (Tan, A. 2016a) and Learning Maths $2 A$ (Tan, A. 2016b). Math ViOlympic 4 and Math ViOlympic 5 are the only two published in Vietnam so far in this realm. From the series published by the foreign publisher, these two books were chosen for analysis as these two are for the children of the same age groups as those in the first set. The number of problems and of running words of the verbal texts in each book is shown in Table 1. vocabulary repetition across the books within each set and across the sets.

\subsection{Procedures}

To achieve the aims, the texts were typed and computerized. The data was first closely analyzed in terms of the distribution of the verbal, visual, and symbolic components. Whereas the statistics of the linguistic and symbolic components were computationally performed, the images were manually calculated. To analyze the vocabulary of the books, the raw data were processed to omit the proper nouns. This is because many researchers have taken the approach that proper nouns may be easily understood by readers (e.g. Nation, 2006); how proper nouns are handled makes a big difference to an output profile (Cobb, 2010). The symbolic components and numbers, which are inherent and pervasive of this genre, were also omitted. The data were then submitted to the vocabulary profile after being converted to text files, using the BNC-20 wordlist.

Table 1. Number of problems and words in individual books analysed

\begin{tabular}{ccc}
\hline Book & No. of Problems & Running words \\
\hline Learning Maths 1B & 381 & 3488 \\
Learning Maths 2A & 393 & 1589 \\
Math ViOlympic 4 & 555 & 5578 \\
Math ViOlympic 5 & 400 & 5141 \\
\hline Total & $\mathbf{1 , 7 2 9}$ & $\mathbf{1 5 , 7 9 6}$ \\
\hline
\end{tabular}

\subsection{Instruments}

The sets of materials were analysed using Compleat Lexical Tutor developed by Tom Cobb (available at http://www.lextutor). VocabProfile gives all the information regarding vocabularies of a text - the number of type, token, word families, type-token ratio, function and content words and even breaks any English text into its frequency levels according to the thousand-levels scheme, Academic and off-list words, indicated by colours. Frequency extracts frequency lists from the corpora. TextLexCompare is used to tract the amount of

\section{Findings and discussion}

4.1. Distribution of the three semiotic resources

As explicated above, the organisation of mathematical printed texts, typically involving three semiotic resources, simultaneously permit segregation and integration of these componential elements. An in-depth analysis of the data, both computationally and manually, yielded insightful findings on the distribution of the resources, as shown in Table 2. 
Table 2. Distribution of three semiotic resources

\begin{tabular}{|c|c|c|c|c|c|}
\hline & \multirow{2}{*}{ Language } & \multirow{2}{*}{$\begin{array}{l}\text { Symbolic } \\
\text { elements }\end{array}$} & \multicolumn{2}{|c|}{ Images } & \multirow{3}{*}{$\begin{array}{l}\text { Total of } \\
\text { Problems }\end{array}$} \\
\hline & & & Illustrative & Integral & \\
\hline & No. (\%) & No. (\%) & No. (\%) & No. (\%) & \\
\hline \multirow{2}{*}{$\begin{array}{l}\text { Learning Maths } 1 B \\
\text { Learning Maths } 2 A\end{array}$} & $30(7.87 \%)$ & $20(5.24 \%)$ & $4(1.04 \%)$ & $351(92.12 \%)$ & 381 \\
\hline & $158(40.20 \%)$ & $301(76.59 \%)$ & $2(0.50 \%)$ & $31(7.88 \%)$ & 393 \\
\hline \multirow{2}{*}{$\begin{array}{l}\text { Math ViOlympic } 4 \\
\text { Math ViOlympic } 5\end{array}$} & $555(100 \%)$ & $241(43.42 \%)$ & $26(4.68 \%)$ & $33(5.94 \%)$ & 555 \\
\hline & $400(100 \%)$ & $214(53.5 \%)$ & $5(1.25 \%)$ & $37(9.25 \%)$ & 400 \\
\hline
\end{tabular}

The most noticeable feature is the presence of all the resources in all the books analysed. However, whereas the Learning Maths series tends to favor symbolic and imageries, the Math ViOlympic series displays an overwhelming predominance of language. All the problems in the Math ViOlympic series are represented via language (100\%); by contrast, images account for less than 10 percent, of which approximately a half are just for the illustrative purpose rather than functioning as an integral component of the problems in question. In other words, these images can be omitted without any inhibition to understanding on the part of the learner.

In the meantime, visuals are always contextualized in relation to the linguistic text and/or the symbolic component in the Learning Maths series. Another significant finding from the data is the particularly high proportion of images in Learning Math $1 B$, which is likely to result from an awareness of the meaningful function of this means in MD in general and its motivating role to YLs of language in particular. Accordingly, in this book, the two other resources make up a mere $7.87 \%$ and $5.24 \%$. Finally, the symbolic component is moderately high in all the three other books $(76.59 \%, 53.5 \%$, and $43.42 \%)$. This result is obviously due to the function of this semiotic resource in MD, as described in the third section.

\subsection{Features of the linguistic text}

To answer the second research question - to what extent doing mathematics in English can be beneficial to the YLs' vocabulary growth, the verbal data were submitted to VocabProfile Frequency, and TextLexCompare. Table 3 and 4 summarize the data in terms of tokens, types, and families of the two corpora, Learning Maths and Math ViOlympic, respectively; the cumulative coverage for each book is shown in Table 5.

Tables 3 and 4 show that the tokens spread over the 20 most frequent 1,000 word families of the BNC. The importance of knowing the most frequent word families is clearly demonstrated in the first rows of these three tables. The first 1,000 word families from the BNC account for up to approximately four-fifths of tokens in the problems in all these books - 76.29\%, $84.02 \%, 84.06 \%$, and $81.13 \%$. For example, regarding Math ViOlympic 4, the first row indicates that 424 different word forms (types) are the source of these 4689 tokens. These 424 types reduce to 303 wordfamilies. Similarly, as for Learning Maths $2 \mathrm{~A}$, the first 1,000 word families account for 1335 of the tokens, 225 of the types, and 173 of the families. It is useful to consider the output in terms of word families because similarity in forms and meanings for tokens from the same family may facilitate understanding and retention. It is also clear that after the second 1,000 word-families, the decreasing rate of the tokens tend to be approximately the same across the four books. From the third-1,000 onwards, the numbers of families thin out rapidly, which 
suggests that the number of low frequency words is few and far between. first 1,000 word-families, the number of the function words tends to double that of the

Table 3. Tokens, types, and families at each level in Learning Maths $1 B$ and $2 A$

\begin{tabular}{|c|c|c|c|c|c|c|}
\hline & \multicolumn{3}{|c|}{ Learning Maths 1B } & \multicolumn{3}{c|}{ Learning Maths 2A } \\
\hline $\begin{array}{c}\text { Word list } \\
(\mathbf{1 , 0 0 0 )}\end{array}$ & Tokens (\%) & Types (\%) & Families & Tokens (\%) & Types (\%) & Families \\
\hline 1 & $2661(76.29)$ & $303(57.71)$ & $231(55.66)$ & $1335(84.02)$ & $223(76.63)$ & $173(75.22)$ \\
2 & $415(11.90)$ & $101(19.24)$ & $80(19.28)$ & $153(9.63)$ & $37(12.71)$ & $31(13.48)$ \\
3 & $35(1.00)$ & $19(3.62)$ & $16(3.86)$ & $29(1.83)$ & $7(2.41)$ & $6(2.61)$ \\
4 & $161(4.62)$ & $32(6.10)$ & $27(6.51)$ & $16(1.01)$ & $7(2.41)$ & $6(2.61)$ \\
5 & $75(2.15)$ & $20(3.81)$ & $18(4.38)$ & $8(0.50)$ & $5(1.72)$ & $5(2.17)$ \\
6 & $59(1.69)$ & $14(2.67)$ & $12(2.89)$ & $33(2.08)$ & $3(1.03)$ & $2(0.87)$ \\
7 & $40(1.15)$ & $14(2.67)$ & $14(3.37)$ & $6(0.38)$ & $3(1.03)$ & $2(0.87)$ \\
8 & $4(0.11)$ & $4(0.76)$ & $4(0.96)$ & & & \\
9 & $4(0.11)$ & $2(0.38)$ & $2(0.48)$ & $4(0.25)$ & $2(0.69)$ & $2(0.87)$ \\
10 & $6(0.17)$ & $3(0.57)$ & $2(0.48)$ & & & \\
11 & $6(0.17)$ & $3(0.57)$ & $3(0.72)$ & $4(0.25)$ & $3(1.03)$ & $3(1.30)$ \\
12 & $1(0.03)$ & $1(0.19)$ & $1(0.24)$ & & & \\
13 & $1(0.03)$ & $1(0.19)$ & $1(0.24)$ & & & \\
14 & $2(0.06)$ & $1(0.19)$ & $1(0.24)$ & & & \\
15 & & & & & & \\
16 & $4(0.11)$ & $1(0.19)$ & $1(0.24)$ & & & \\
17 & & & & & & \\
18 & & & & & & \\
19 & $4(0.11)$ & $2 .(0.38)$ & $2(0.48)$ & & & \\
20 & $10(0.29)$ & $4 .(0.76)$ & $? ?$ & $1(0.06)$ & $1(0.34)$ & \\
\hline Off-List & $3488(100)$ & $525(100)$ & $415+?$ & $1589(100)$ & $291(100)$ & $230+?$ \\
\hline Total & &
\end{tabular}

Table 4. Tokens, types, and families at each level in Math ViOlympic 4 and 5

\begin{tabular}{|c|c|c|c|c|c|c|}
\hline & \multicolumn{3}{|c|}{ Math ViOlympic 4 } & \multicolumn{3}{c|}{ Math ViOlympic 5 } \\
\hline $\begin{array}{c}\text { Word list } \\
(\mathbf{1 , 0 0 0})\end{array}$ & Tokens (\%) & Types (\%) & Families & Tokens (\%) & Types (\%) & Families \\
\hline 1 & $4689(84.06)$ & $424(70.78)$ & $303(69.82)$ & $4171(81.13)$ & $290(67.29)$ & $226(65.89)$ \\
2 & $482(8.64)$ & $92(15.36)$ & $72(16.59)$ & $529(10.29)$ & $77(17.87)$ & $65(18.95)$ \\
3 & $109(1.95)$ & $23(3.84)$ & $22(5.07)$ & $105(2.04)$ & $17(3.94)$ & $15(4.37)$ \\
4 & $51(0.91)$ & $17(2.84)$ & $11(2.53)$ & $120(2.33)$ & $16(3.71)$ & $11(3.21)$ \\
5 & $78(1.40)$ & $11(1.84)$ & $8(1.84)$ & $51(0.99)$ & $11(2.55)$ & $9(2.62)$ \\
6 & $86(1.54)$ & $6(1.00)$ & $4(0.92)$ & $72(1.40)$ & $6(1.39)$ & $5(1.46)$ \\
7 & $5(0.09)$ & $4(0.67)$ & $2(0.46)$ & $1(0.02)$ & $1(0.23)$ & $1(0.29)$ \\
8 & $11(0.20)$ & $5(0.83)$ & $5(1.15)$ & $63(1.23)$ & $4(0.93)$ & $3(0.87)$ \\
9 & $3(0.05)$ & $1(0.17)$ & $1(0.23)$ & $5(0.10)$ & $3(0.70)$ & $3(0.87)$ \\
10 & $43(0.77)$ & $3(0.50)$ & $3(0.69)$ & $8(0.16)$ & $2(0.46)$ & $2(0.58)$ \\
11 & & & & & & \\
12 & & & & & & \\
13 & $1(0.02)$ & $1(0.17)$ & $1(0.23)$ & $8(0.16)$ & $1(0.23)$ & $1(0.29)$ \\
14 & & & & $7(0.14)$ & $2(0.46)$ & $2(0.58)$ \\
15 & $1(0.02)$ & $1(0.17)$ & $1(0.23)$ & & & \\
16 & $1(0.02)$ & $1(0.17)$ & $1(0.23)$ & & & \\
17 & & & & & & \\
18 & & & & & & \\
19 & & & & & & \\
20 & & & & & & \\
\hline Off-List & $18(0.32)$ & $10(1.67)$ & $?(10.02)$ & $1(0.23)$ & $?$ \\
\hline Total & $5578(100)$ & $599(100)$ & $434+?$ & $5141(100)$ & $431(100)$ & $343+?$ \\
\hline
\end{tabular}

As shown in Table 6, it is also important to note that of these huge coverages of the content words throughout the data.

Assuming that proper nouns and 
Table 5. Cumulative coverage (\%) for each book

\begin{tabular}{|c|c|c|c|c|}
\hline Word list & Learning Maths $1 B$ & Learning Maths $2 A$ & Math ViOlympic 4 & Math ViOlympic 5 \\
\hline 1,000 & 76.29 & 84.02 & 84.06 & 81.13 \\
\hline 2,000 & 88.19 & 93.65 & 92.70 & 91.42 \\
\hline 3,000 & 89.19 & 95.48 & 94.65 & 93.46 \\
\hline 4,000 & 93.81 & 96.49 & 95.56 & 95.76 \\
\hline 5,000 & 95.96 & 96.99 & 96.96 & 96.78 \\
\hline 6,000 & 97.65 & 99.07 & 98.50 & 98.18 \\
\hline 7,000 & 98.80 & 99.45 & 98.59 & \\
\hline 8,000 & 98.91 & & & 98.20 \\
\hline 9,000 & 99.02 & 99.70 & 98.79 & 99.43 \\
\hline 10,000 & 99.19 & & 98.84 & 99.53 \\
\hline 11,000 & 99.36 & 99.95 & 99.61 & 99.69 \\
\hline 12,000 & 99.39 & & & \\
\hline 13,000 & 99.42 & & & \\
\hline 14,000 & 99.48 & & & \\
\hline 15,000 & & & 99.63 & 99.85 \\
\hline 16,000 & & & & 99.99 \\
\hline 17,000 & 99.59 & & 99.65 & \\
\hline 18,000 & & & 99.67 & \\
\hline 19,000 & 99.70 & & & \\
\hline 20,000 & & & & \\
\hline Off-List & 99.99 & 100.00 & 99.99 & 100.00 \\
\hline Tokens & $\approx 100.00$ & $\approx 100.00$ & $\approx 100.00$ & $\approx 100.00$ \\
\hline
\end{tabular}

Table 6. K-1 sub-analysis in terms of content and function words for individual books

\begin{tabular}{c|c|c|c|c}
\hline K1 Words & Math ViOlympic 4 & Math ViOlympic 5 & Learning Maths 1B & Learning Maths 2A \\
\hline Function words & $59.27 \%$ & $52.69 \%$ & $46.40 \%$ & $50.16 \%$ \\
Content words & $27.54 \%$ & $31.24 \%$ & $31.17 \%$ & $34.36 \%$ \\
\hline
\end{tabular}

mathematical symbolism are repeatedly present, the findings suggest that only a small vocabulary is needed for YLs to comprehend these mathematic problems. The number of word-families a learner would meet when s/he finished Math ViOlympic 4, Math ViOlympic 5, Learning Math $1 B$, and Learning Math $2 A$ is $434^{+}$, $343^{+}, 415^{+}$, and $230^{+}$, respectively. The data was shown to contain not only a small number of word-families but also a high frequency rate of encounter of each word, which is strikingly similar across the two series. A small number of these word families are met from as high as 592 to six times $(64.32 \%, 86.94 \%, 76.28 \%$, and $70.35 \%$ ). The overall and unexpected finding from a close analysis of the lists of frequency indicates that these soaring high percentages are typically represented by function words and technical words. By contrast, a substantial majority occur merely once or twice in each book (Table 7). It should also be noticed that tokens from this low-frequency group typically lie with everyday common vocabulary for Y Ls' world, namely family, school, animals, and fruits.

Incidental learning theory indicates that if unknown words are repeatedly encountered in meaningful contexts, their meaning will gradually be acquired (Nagy et al., 1985). Research into L2 reading suggests that if unknown words are encountered six or more times, there is the potential for incidental learning (Rott, 1999). Acquisition of word meaning is also dependent on the contexts of encounters (Webb, 2008). If words repeatedly occur in highly informative contexts, their meanings may be learned after a small number of encounters. By contrast, in less informative and/or misleading contexts, it could take as many as 20 encounters for unknown words to be learned (Webb, 2010). Therefore, it is 
possible to deduce from the findings that the chance for vocabulary growth in common age-specific topics via doing ME is minimal. offering penetrating insights into the functions of the semiotic resources, individually and integrally.

Table 7. Number and percentage of encounters with word families (WF) in each book

\begin{tabular}{|c|c|c|c|c|c|c|c|c|}
\hline & \multicolumn{2}{|c|}{ Math ViOlympic 4 } & \multicolumn{2}{c|}{ Math ViOlympic 5 } & \multicolumn{2}{c|}{ Learning Math 1B } & \multicolumn{2}{c|}{ Learning Math 2A } \\
\cline { 2 - 8 } & $\%$ & No. of WF & $\%$ & No. of WF & $\%$ & No. of WF & $\%$ & No. of WF \\
\hline 6 times \& $>$ & 64.32 & 165 & 86.94 & 153 & 76.28 & 146 & 70.35 & 64 \\
5-3 times & 26.75 & 111 & 7.9 & 108 & 12.44 & 121 & 14.95 & 67 \\
2-1 times & 8.93 & 370 & 5.15 & 214 & 11.28 & 299 & 14.7 & 167 \\
\hline
\end{tabular}

Table 8. Recyclying index over each set

\begin{tabular}{|c|c|c|}
\hline & Math ViOlympic 4 \& Math ViOlympic 5 & Learning Maths 1B \&Learning Maths 2A \\
\hline Token & $84.84 \%$ & $74.94 \%$ \\
Type & $55.46 \%$ & $49.47 \%$ \\
\hline
\end{tabular}

A further analysis by means of TextLexCompare yields the percentage of recycled vocabulary in each set of data, summarized in Table 8 . The output shows that the recycling index does not go above $85 \%$ for either set. This means that many or most words throughout the two successive books of each set are being met in density environments of around 3 unknown words in 10 , which doubles the density that learners can handle. Research indicates that for learners to be able to guess words in context and gain adequate comprehension of written text it is necessary to know at least $95 \%$ of the words (Laufer, 1989). Moreover, comprehension and incidental vocabulary learning through reading are likely to increase if the percentage of known words in a text is $98 \%$ (Nation, 2001). This result significantly supports the finding that there may be very little incidental vocabulary learning from doing $\mathrm{ME}$ for primary school children.

\section{Conclusions}

The study is inspired by an appreciation of the multisemiotic nature of MD. This is essentially a new approach to mathematics for teachers and students of mathematics,
Overall, although all the three semiotic resources are manipulated in all the books analyzed, the distribution of each tends to be unequal between the two series analyzed. The visual component fails to be paid due attention in the Math ViOlympic series, which displays an overwhelming predominance of the linguistic text. An opposite extreme can be found in the Learning Math series. As indispensable as symbolism is in $\mathrm{MD}$, this resource is represented by a moderately high percentage in all of the books analyzed.

Lexical profile analysis shows that learners who finish both these books are likely to encounter frequent words (at the 1000 level) enough to make significant gains in vocabulary knowledge, with particular reference to technical mathematic-specific terms; however, Frequency analysis indicates that around one half of the word-families will not be met sufficiently for incidental learning of vocabulary to occur. Text comparison analysis further shows that the rate of new word introduction in the higher-level book in each set is more than most L2 learners will be able to cope with. 


\subsection{Pedagogical implications}

The results of the close analysis from a multisemiotic perspective have immediate pedagogical implications as follows.

First, the test-orientated books published by Vietnam Education Publishing House are claimed "help students familiarize with the fascinating test format, thinking stimulation and computer practice before competition. [...] to get the best competition score" (Đặng Minh Tuấn \& Nguyễn Thị Bích Phượng, 2016, p.3). The market-driven practices have also resulted in these materials with a predominance of the linguistic and symbolic components. The findings therefore indicate an urgent need for producing researchinformed graded materials beyond those presently available in which we should not lose sight of the multi-semiotic nature of MD. Mathematical symbolism and visual images have evolved to function in co-operation with language. As "the visual image plays an increasingly important role in different branches of mathematics" (O'Halloran, 2004, p.148), with the impact of increased computational ability, colorful computergenerated visual images can now be generated with minimal effort. Captivatingly presented, these materials for primary-school children may be of greatest importance to get learners accustomed to MD in English as a foreign language and to help them meet the initial challenge in content-language integrated learning that ME may at first present.

Second, for the Vietnamese YLs, although incidental vocabulary learning may occur through finishing the two books, the number of words outside this specific domain which can be acquired is likely to be limited. Thus, teachers and learners should not consider vocabulary learning as the primary goal of doing ME. Learners may undoubtedly benefit from other explicit ways to learn vocabulary than through doing ME. To facilitate understanding, it may be necessary for teachers either to encourage guessing from context or to provide glossaries so that learners can check L1 translations quickly when necessary.

\subsection{Implications for further research}

The data we have looked at in this article suggest the following considerations for further studies.

First, given the dearth of graded materials in this area, there should be more research to select and sequence resources, integrating text-based with Internet-based texts, and to provide smooth, principled access to them. In addition to the obviously primary goal of systematically targeting the field-specific needs, efforts can be made to help facilitate vocabulary growth opportunities that these materials can offer. Frequency profiling software can be used to modify and create texts to pre-specified lexical profile and coverage; and text comparison software can be used to ensure degree of lexical recycling over a series of chapters, books, and series.

Second, the results of the present study suggest there may be potential for incidental learning of the first 1,000 wordfamilies through engaging the YLs in doing mathematics in English. However, while this is a useful finding, further research to examine experimentally through a controlled treatment with the learners to provide a more accurate assessment of the extent of transferring new word learning to novel contexts is needed. In addition, the sub-dimensions to the basic learning condition, such as the spacing between encounters should be taken into consideration.

\section{References}

Đặng Minh Tuấn \& Nguyễn Thị Bích Phượng (2016). Math ViOlympic 5. Hanoi: Vietnam Education Publishing House.

Đặng Minh Tuấn \& Nguyễn Thị Hải (2016). Math ViOlympic 4. Hanoi: Vietnam Education Publishing House. 
Cobb, T. (2010). Learning about language and learners from computer programs. Reading in a Foreign Language, 22(1), 181-200.

Krashen, S. (1989). We acquire vocabulary and spelling by reading: Additional evidence for the input hypothesis. The Modern Language Journal, 73, 440-464.

Krashen, S. (2003). Explorations in language acquisition and use: The Taipei lectures. Portsmouth, NH: Heinemann.

Laufer, B. \& Sim, D. D. (1985). An attempt to measure the threshold of competence for reading comprehension. Foreign Language Annals, 18 (5), 405-411.

Laufer, B. (1989). What percentage of text lexis is essential for comprehension?. In C. Lauren \& M. Nordman (Eds.), Special Language: From Humans Thinking to Thinking Machines, 316-323. Clevedon: Multilingual Matters.

Nagy, W. E., Herman, P. \& Anderson, R. C. (1985). Learning words from context. Reading Research Quarterly, 20(2), 233-253.

Nation, I. S. P. (2001). Learning Vocabulary in Another Language. Cambridge: Cambridge University Press.

Nation, I.S.P. (2004). A study of the most frequent word families in the British National Corpus. In P. Bogaards \& B. Laufer (Eds.), Vocabulary in a second language: Selection, acquisition, and testing, 3-13.
Amsterdam: John Benjamins.

Nation, I.S.P. (2006). How large a vocabulary is needed for reading and listening? The Canadian Modern Language Review, 63(1), 59-82.

O'Halloran, K. L. (2004). Mathematical discourse language, symbolism and visual images. London: Continuum.

Rott, S. (1999). The effect of exposure frequency on intermediate language learners' incidental vocabulary acquisition through reading. Studies in Second Language Acquisition, 21(1), 589-619.

Tan, A. (2016a). Learning Maths - 1B. (Bilingual version). Singapore Asia Publishers.

Tan, A. (2016b). Learning Maths - 2A. (Bilingual version). Singapore Asia Publishers.

Webb, S. (2007). The effect of repetition on vocabulary knowledge. Applied Linguistics, 28(1), 46-65.

Webb, S. (2008). The effects of context on incidental vocabulary learning. Reading in a Foreign Language, 20(2), 232-245.

Webb, S. (2010). A corpus driven study of the potential for vocabulary learning through watching movies. International Journal of Corpus Linguistics, 15(4), 497-519.

\title{
PHÂN TÍCH ĐA THỨC DIỄN NGÔN TOÁN BẦNG TIẾNG ANH DÀNH CHO LỬA TUỔI TIỂU HỌC
}

\author{
Tôn Nữ Mỹ Nhật \\ Khoa Ngoại ngũu, Truờng Đại hoc Quy Nhơn, \\ 170 An Dưong Vưong, Tp. Quy Nhơn, Bình Định, Việt Nam
}

Tóm tắt: Trẻ em Việt Nam ngày càng được tiếp cận nhiều thể loại nhằm phát triển năng lực tiếng Anh, trong số đó có các môn khoa học tự nhiên như môn Toán. Bài viết này khảo sát thể loại diễn ngôn này từ góc nhìn đa tín hiệu. Cụ thể, công trình này nghiên cứu: (1) phân bố của ba loại tín hiệu trong các tài liệu giải toán bằng tiếng Anh dành cho học sinh tiểu học; và (2) số lượng từ vựng yêu cầu đối với người học để giải các bài toán bằng tiếng Anh dành cho học sinh tiểu học. Dữ liệu nghiên cứu là các sách luyện toán bằng tiếng Anh đang được sử dụng phổ biến ở Việt Nam. Kết quả nghiên cứu cho thấy ý nghĩa giao tiếp của hai loại tín hiệu ký hiệu và hình ảnh đối với thể loại diễn ngôn khoa học này, bên cạnh tín hiệu ngôn ngữ, và các cấp độ từ vựng tiếng Anh đối với người học để có thể hiểu được các bài toán đặt ra. Cuối cùng là một số thảo luận về ý nghĩa thực tiễn đối với công việc biên soạn tài liệu, dạy và học toán bằng tiếng Anh đối với lứa tuổi tiểu học.

Tù khóa: diễn ngôn toán, diễn ngôn đa thức, danh sách các từ thông dụng 